\title{
METHODICAL BASES OF FORMATION OF INVESTMENT POLICY OF ENTERPRISES OF CONSTRUCTION MATERIALS INDUSTRY
}

\author{
Oksana Aleksandrovna Baulina, ${ }^{1, a}$, Vladislav Vladimirovich Klyushin, ${ }^{2, b, *}$ \\ ${ }^{1}$ Krasnoznamenskaya St., 25, apartment 63, 400066, city of Volgograd, Russian Federation \\ ${ }^{2}$ Krasnoznamenskaya St., 25, apartment 63, 400066, city of Volgograd, Russian Federation \\ abaulina-oksana@yandex.ru, bvladislav-klushin@yandex.ru \\ *Corresponding author
}

Cite as: Baulina, O.A., Klyushin, V.V. (2017). Methodical bases of formation of investment policy of enterprises of construction materials industry, Ekonomicko-manazerske spektrum, 11(2), 1-12.

Available at: dx.doi.org/10.26552/ems.2017.2.1-12

\begin{abstract}
In the present paper proved the feasibility of allocation of the investment component of the stability of the enterprises (along with financial, economic, organizational) in the formation of investment policy of enterprises of construction materials industry. The author analyses the techniques used in the estimation of the factors and indicators of financial, economic, institutional and investment components stability of enterprises, including enterprises of material and technical base of construction. Comparative analysis of results to test these methods on the example of the enterprises of building materials industry, operating in the Volgograd region. Identified and justified the advantages and disadvantages of their use in the development of the investment policy of the enterprises, functioning on the principle of the closed cycle of production. In paper as authors definition of the following concepts "investment component of stability of the enterprise", "investment niche of the enterprise", "investment lag" is given. Also proved the feasibility of taking into account these definitions in assessing the investment activity of enterprises with closed cycle of production of building materials industry and the development of the investment policy of the enterprises. Also the proposed method of evaluation of indicators such as "investment niche" and "the duration of the lag of investment", the use of which allows to determine the position of industrial enterprises of building materials in coordinate system "time - investment". The paper formulates principles and develops a structural and logical model of formation of investment policy of the enterprises of a closed cycle of production, taking into account the prognostic assessment of investment niches and the duration of investment lag. Also formulated the goal and objectives of the investment policy of the enterprise, the principles developed and presented the structurallylogic scheme of formation of investment policy of enterprises of construction materials industry.
\end{abstract}

Keywords: investment niche, investment lag, duration of investment lag, investment, stability of the enterprise, investment policy, construction materials industry

JEL Classification: R11, R15, P41

\section{Introduction}

The problem for the stable functioning of economic entities is one of the key problems today. Despite the fact that at the present time, the tendency of transition of Russian companies to the 


\section{Methodical Bases of Formation of Investment Policy of Enterprises of \\ Construction Materials Industry \\ Authors: Oksana Aleksandrovna Baulina, Vladislav Vladimirovich Klyushin}

strategy of stabilization and gradual growth, investment activity remains at a low level. (Kosnik, 1987) This trend is observed both in Russia as a whole and in individual regions, industries, including in the building materials industry. For example, in 2016 the share of enterprises of the analyzed sector of the Volgograd region in the total volume of investments in fixed capital amounted to $1.33 \%$ (whereas, for example, enterprises of chemical and petrochemical industry is $13.9 \%$, fuel industry $29,7 \%$ ). (Feroz et al., 1991; Palepu, 1986)

This is largely due to the lack of a clear investment policy, both at the level of enterprises and at the level of the industry as a whole. (Novikova et al., 2016) Usually at the enterprise level the purpose of the investment policy is the identification of priority areas for investment and the establishment of the optimal (by the criterion of competitiveness of the enterprise) resource allocation between them. (Jensen, 1983) Under this offer investors the programmes and projects are developed based on the results of assessment factors and indicators of financial and economic factors the stability of enterprises, the allocation and analysis of investment stability. This approach is not always justified, since the question of objective estimation of opportunities of the enterprise to attract investment resources and needs of the enterprise in such resources, is not sufficiently studied. (Jensen \& Meckling, 1976) While the study and evaluation of factors and indicators of investment stability of the company determines the optimal investment policy of an enterprise, and therefore the attractiveness of the projects and programs of the company for the potential investor. (Pincus et al., 1989)

Consider what factors and indicators assessed the investment component of the enterprise stability and further developed the investment policy of the company. In practice measured such factors that affect the stability of businesses (including construction companies) as: investment attractiveness, investment activity, investment risks, investment potential. In assessing these factors uses the methods of calculation of the net discounted income, internal rate of return, profitability index, profitability, payback period, risk level. These indicators reflect the efficiency of a specific investment project. (Patton \& Baker, 1987) With regard to the definition of efficiency of investment activity of the enterprise carried out separately or in the process of participation in implementation of investment projects of other companies, that are used for the assessment of such indicators as: the total volume of investments in fixed capital, accumulated investments during the period, the investment growth rate, the share of reinvested profits in total investment, the additional output per unit of investment, cost reduction. But given these parameters difficult predictive assessment of the prospects of investment activity of enterprises. (Rosenstein \& Wyatt, 1990)

Current negative trends in the regional construction industry necessitated the search of theoretical and methodical substantiation of a number of new factors and indicators, based on the consideration in which the formation of the investment policy of the company. These include such factors as the adaptability of the investment (calculated using the method of fuzzy sets, the method of the regression estimator, administrative-economic method), investment capacity (calculated using the method of the Express analysis), investment transparency (to assess used the method of expert scoring). (Shivdasani, 1993)

Evaluation of investment adaptability allows you to identify opportunities for flexible restructuring of the enterprise to changing external influences to the environment. In the strategic plan consideration of this factor provides a great opportunity. However, it is necessary to Supplement it with a number of concepts that will determine not only the behavioral possibilities of the enterprise, but to capture these opportunities in the coordinate system "time - investment" in the future. In particular, such factors are "niche investment" and "investment lag". All of the above factors and indicators, including "investment niche" and "the duration of 
the lag investment," determine the level of investment activity and, consequently, its investment component stability. (Morck et al., 1988)

The need to elaborate the theoretical and methodological support of these factors and indicators, based on the consideration which the appropriate formation of the investment policy of the enterprises of a closed cycle of production led to the relevance and choice of the research topic. (DeAngelo, 1990; DeAngelo et al., 1994) Various aspects of stability assessment of enterprises, including enterprises of the building industry, dedicated to a sufficiently large number of works by scholars and practitioners. So, the study of the component factors of financial stability of enterprises, the development of methodological approaches to the assessment of financial performance dedicated to Shleifer, and Vishny (1986).

Such scientists as Sommer (1991) or Stone and Rasp (1991) explore the factors and indicators of economic and financial component of the enterprise's stability, offer methodological approaches to assessing the feasibility, financial performance. In the works of Vancil (1987) explores factors of the organizational component of the enterprise's stability, such as the optimality of organizational structure, level of corporate culture. The study of factors and indicators investment component of stability of the enterprise are devoted to the work of Vicknair et al. (1993), Warner et al. (1988). These scientists examine the theoretical and methodical grounds of assessment of efficiency of investment policy, analysis and assessment of the investment climate, investment attractiveness, investment risks, investment adaptability of socio-economic systems (regions, industries, enterprises).

However, despite the variety of developed and applied methods to assess the stability of the enterprise and its components, there still exists the problem associated with obtaining complete picture about the stability of enterprises in particular investment stability. Unreached and unexplored factors remain the investment component of the enterprise's stability as an «investment niche» and «investment lag», which play a significant role in the development of the investment policy of the company. (Weisbach, 1988)

\section{Methodology}

The purpose of this study is development of methodical providing of process of forming of the investment policy of industrial enterprises of building materials on the basis of the identification and evaluation of investment niche and lag investment. The achievement of the research objectives will be achieved through addressing the following interrelated tasks: to prove the appropriateness of the allocation of the investment component of the stability of the enterprise in the formation of investment policy of enterprises of construction materials industry; to systematize the conceptual apparatus of the study; to supplement and clarify the factors and indicators of investment activity of enterprises taken into account during the development of the investment policy of the enterprises of building materials industry, to create methodical approaches to the assessment of investment niche and lag of investment; to formulate principles and develop a model of formation of investment policy of enterprises of building materials industry, operating on the principle of the closed cycle of production, taking into account the prognostic assessment of investment niche and lag investment.

Subject of research are communications, relationships and processes emerging in the investment sphere of functioning of the enterprises of material and technical base of construction. (Jensen, 1993) The object of the study are enterprises of construction materials industry of one of the regions of the Russian Federation - Volgograd region. Methodological and theoretical base of research are the concepts and hypotheses, grounded in modern economic literature, normative-methodological, legislative and forecast of the development of state and 


\section{Methodical Bases of Formation of Investment Policy of Enterprises of \\ Construction Materials Industry \\ Authors: Oksana Aleksandrovna Baulina, Vladislav Vladimirovich Klyushin}

regional governments. (Maddala, 1991) The study used a multidisciplinary and systemic approaches, methods of economic-statistical, mathematical, comparative analysis. The empirical base of research are materials of the Federal service of state statistics of the Russian Federation, expert evaluation of phenomena and processes, analytical data, published scientific literature and periodicals, as well as our own research and the authors calculations at the industry level. (Palmrose, 1987) Practical significance of the research consists in possibility of use of the results by authorities, enterprises of building materials industry, the formation of investment policy for specific enterprises, comprehensive diagnostic stability of enterprises, the development of the actions directed on activization of investment process in the construction industry.

\section{Results}

Stability as a state of dynamic equilibrium of an enterprise, that maintains predictable and long-term evolutionary viability through qualitative and quantitative growth, is determined by the efficiency of interaction of the enterprise with the external environment. In the course of this interaction there is an exchange of resources: material, financial, material and intellectual labor. Participating the investment of these resources in the implementation of projects and programs, the company is actually investing them. Competitive advantage in achieving stability acquire those businesses that most effectively utilize both internal and external investment resources by implementing an optimal investment policy.

However, as practice shows, the preparation of documents for obtaining investment, more attention is paid to the assessment of indicators characterizing the factors of financial, economic and organizational components of less stability of enterprises of the construction industry. As for the investment component, as a rule, is the level of investment risk and investment attractiveness. The first factor is purely subjective, due to the lack of an information base on market and industry risks, the second is determined based on an assessment of indicators such as profitability, payback period. In our opinion, the ability to work with investment is characterized by several other factors, influencing its investment activity. In the latest developments on this issue describes the factors such as investment transparency, investment adaptability. In addition to these factors, we propose to consider the investment niche of the enterprise and the lag of investment, which inevitably occurs during the development of their investment resources. Carrying out investment activity in the environment, companies form the investment niche, defined by a set of investors whose resources can be mobilized and utilized for the expanded reproduction of its own resources. (Kaplan \& Reishus, 1990)

If the enterprise operates in the absence of acute competition in attracting investment resources, the investment niche is defined as "potential". The investment niche, which is formed under the influence of the overlapping of the niches of the investment, is defined as "actual" investment niche businesses, which is always smaller than the potential niche or equal to it. In practice, investment niches, as a rule, overlap partially, i.e. some investment resources are shared and others are used exclusively by one or other business entity (Fig. 1). 
Figure 1: Graphical interpretation of the effect of the overlapping of the investment niches of the companies $A$ and $B$

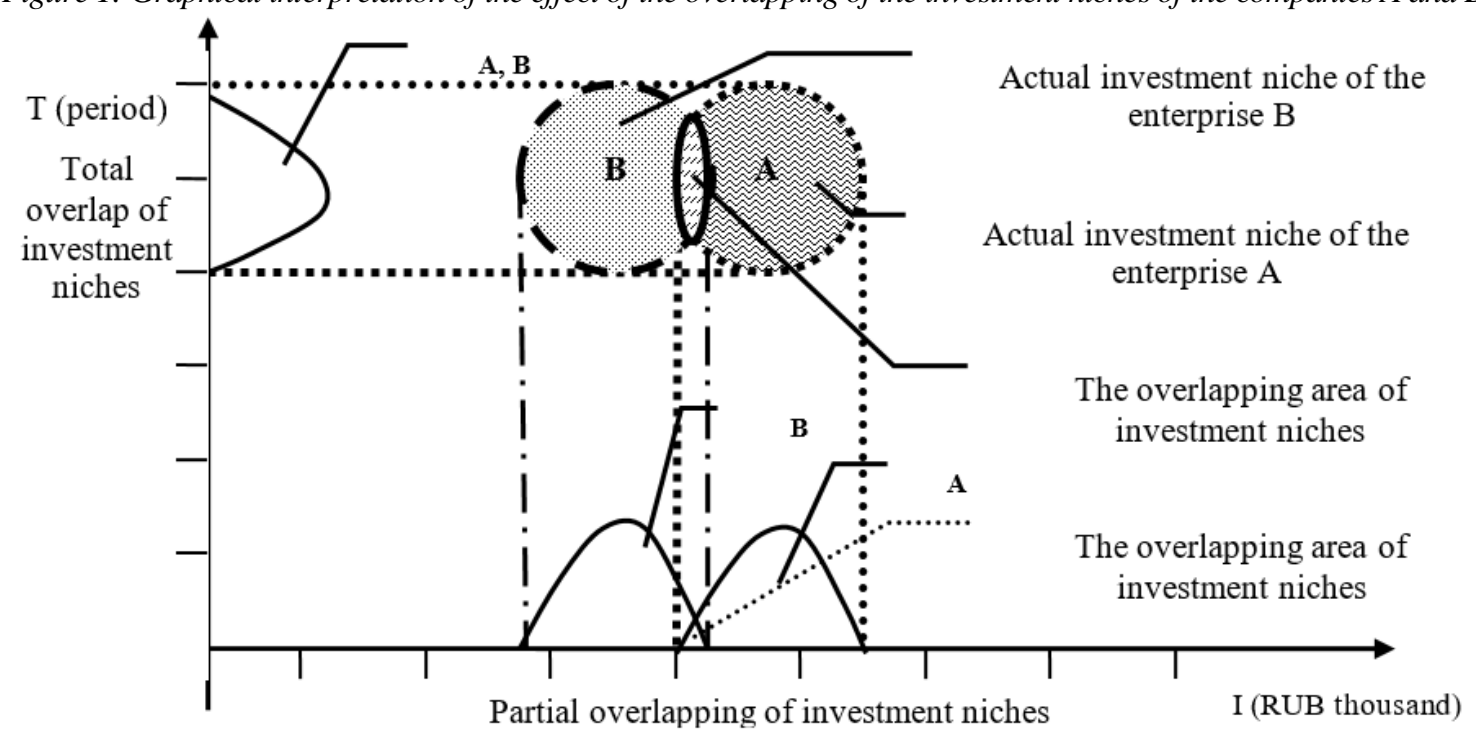

Source: The drawing is made by results of researches of authors

Assessing the investment component of the enterprise's stability, it is necessary to proceed from the fact that the investment activity of enterprises may not be the same always, she has "bursts" and "decay". Because of this be limited in the evaluation of the investment component of the enterprise's stability with the consideration of indicators of investment activity without taking into account the analysis of the duration of investment lag is not quite right it can lead to incorrect conclusions when developing programs of development of the enterprise. (Baysinger \& Butler, 1985)

Since the optimum moment of beginning realization of the next investment project is the time increment of investment capacity of the enterprise due to the implementation of the previous project, low values of indicators of investment activity may be the evidence of the existence of problems in the sphere of investment activity of the enterprise and on the optimality of the investment policy of an enterprise (Fig. 2). Indicators based on the calculation of estimated selected factors of the investment component stability businesses are: investment niches - the total foreign and domestic investment resources, which may be held by the enterprise for investment activity at this stage of operation, (Vin); and the duration of investment lag - the time lag between the increment of investment capacity of the enterprise due to the implementation of the i-th investment project and the beginning of i+1 of an investment project (TIP).

Investment niches and the duration of the lag of investment are subject to control, the purpose of which is to minimize the negative impact on the level of the investment component of the enterprise's stability objectively existing effect of the overlapping of the niches of the investment and ensuring the investment activity of enterprises under all possible changes in the environment. (Gilson, 1990) Used in economic practice methodological approaches to assessing the stability of the enterprise, as a rule, are based on: studying the factors and indicators of financial and economic activities, assessment of the prospects of investment development of the enterprise using the methods of financial and investment analysis. 


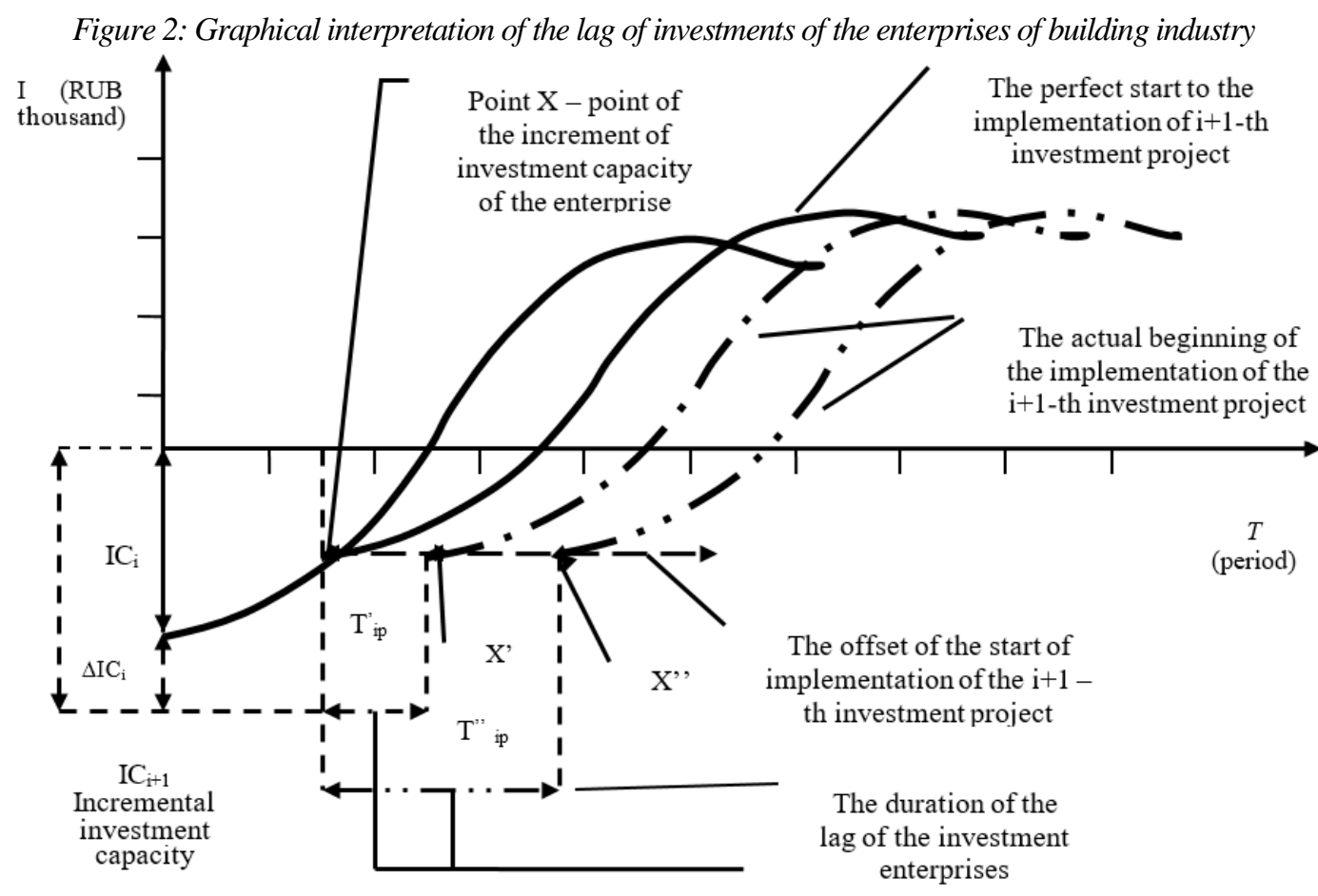

Source: The drawing is made by results of researches of authors

The indicated methods were used in the study of problems and prospects of development of enterprises of construction materials industry of the Volgograd region for the period from 2012 to 2016, the result of which revealed the following:

- the share of the industry of construction materials in the Volgograd region accounted for $4.7 \%$ of the total volume of industrial production (2016), where about 1 percent of total employment in the industry,

- regional commodity market is saturated construction materials, at the same time, the range of local producers does not fully meet the needs of modern construction, as evidenced by the significant share of imported construction materials (50\%),

- there is a low utilization of the production capacities of industrial enterprises of building materials in the Volgograd region (about 57\%), a significant depreciation of fixed assets (64.3 percent) and low level of investment activity in the industry as a whole,

- a decrease in the rate of growth of investment in fixed capital of enterprises of the studied sector. The share of enterprises of construction materials industry in the total volume of investment in fixed capital remains low with $1.33 \%$ (Fig. 3),

- only $60 \%$ of the total number of enterprises operate with positive financial results, investment activity is carried out by $80 \%$ among large and medium enterprises of construction materials industry and only $1 \%$ for small businesses, the main sources of investments are own funds of enterprises,

- the main objectives of investment in fixed assets are: replacement of worn-out machinery and equipment (64\% of the total number of enterprises), the introduction of new production technologies (58\%), energy savings (56\%),

- according to forecasts, in 2018 , only $40 \%$ of companies in the industry are planning increased investment in fixed assets, more than one third - reduce the amount of, every fifth company has no plans to engage in investment activity,

- the main factors constraining investment activity of regional enterprises of construction materials industry, is the insufficient volume of investment niches, due to the low figures 
of financial and industrial-economic activities, as well as long-lasting investment pause. (Grossman \& Hart, 1980)

Figure 3: Dynamics of specific weight of industrial enterprises of building materials in the Volgograd region in total volume of investments in fixed assets in 2012-2016

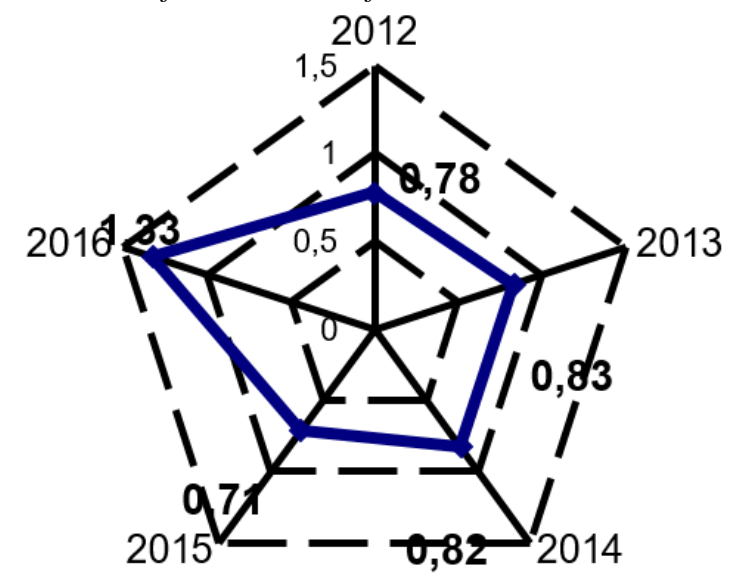

Source: The drawing is made by results of researches of authors

The study was conducted to assess the factors and indicators of financial and economic components of the stability of the four enterprises of the industry of construction materials in the Volgograd region: JSC "Company ZHBI-6" JSC "Promstroykonstruktsiya", LLC "Volgograd Plant Of Building Materials", LLC "Hearth" using the method proposed by the company LLC "National Real Estate Agency" (Moscow). The result that was identified similar problems in the field of production and marketing activities, logistics, which in turn affect investment opportunities in these companies - their narrow investment niches and increase the duration of the investment pauses. In particular, in the framework of this methodology was the ratio of "sustainability risk" to the above businesses. (Fama, 1980)

The most stable is the company LLC "Volgograd Plant Of Building Materials", followed by JSC "Company ZHBI-6", which has a moderate degree of risk of loss of economic stability, in third place - JSC "Promstroykonstruktsiya", fourth - LLC "Hearth", which is not economically stable. (Hermalin \& Weisbach, 1988; Hermalin \& Weisbach, 1991)

To check the accuracy of the results was the estimation of the factors and indicators of financial and economic components of the stability of these enterprises. With this purpose, we used techniques of financial analysis. Next was the evaluation factors and indicators of the investment component of the stability of the above-named companies. In particular, it was found that the investment activity of enterprises is low.

However, based on these estimates no conclusion can be drawn about the real possibilities of the enterprises to participate in investment activities, because each of them occupies its investment niche and target changes its volume, governs the duration of investment lag. We believe that the study of these factors allows to develop an optimal investment policy of the enterprise aimed at increasing investment activity. Thus, the results of the evaluation of investment niches showed that in 2016 the company really could not increase their investment activity, since the existing ratio of the volume of investment niches and investment capacity, exceeding the investment needs over the possibilities of satisfying them (Fig. 4). 
Figure 4: The ratio of the volume of the investment niches of enterprises of construction materials industry of the Volgograd region and their investment capacity on 01.12.2016.

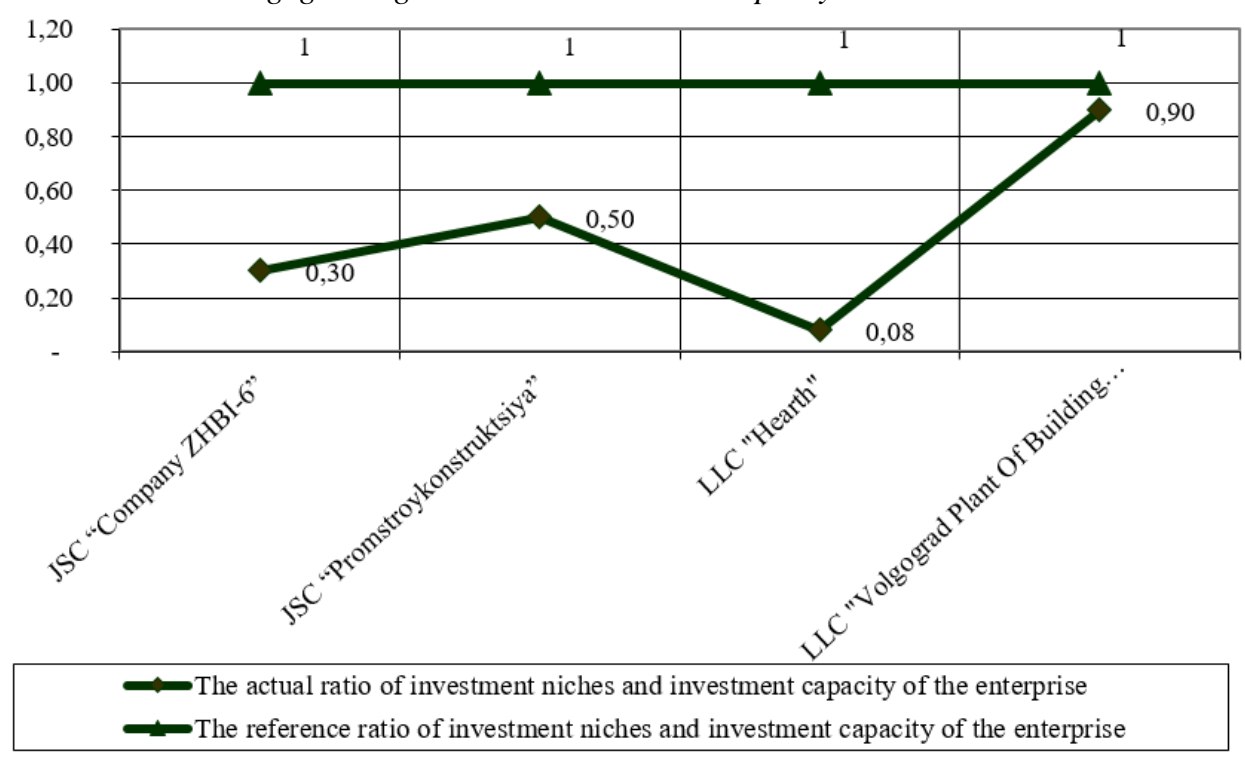

Source: The drawing is made by results of researches of authors

The results of the evaluation of the duration of the lag of investments in the activities of these companies confirmed the conclusion about the extremely low level of investment activity, as well as the assumption about the ineffectiveness of the investment policy of the company. So, for example, for JSC "Company ZHBI-6" the length of the actual lag of the investments was 8 months, with "reference" in 4 months.

The investment policy of the enterprises of the construction industry is defined as the set of actions of management of the enterprise in the development and implementation of optimal management decisions in the financial, economic, operational, organizational, investment and other activities, taking into account objectively existing ratio of the amount of investment niches of the company and its investment capacity, aimed at optimization of investment niches and the duration of the lag of investments in the framework of the strategic goals.

The purpose of the investment policy is to achieve and maintain the stability of enterprises in the context of financial, economic, institutional and investment components. The achievement of this goal is ensured by the following tasks: 1. to optimise the amount of investment niches of the enterprise; 2 . optimization of the length of the lag of investments of the enterprise; 3 . effective involvement of resources in the investment process, characterized by the increment of investment potential of the company.

The main principles of formation of investment policy of the company are: unity, participation, continuity, flexibility and precision. The most important conditions necessary for the formation of efficient investment policy of the company we include a high level of organizational and investment culture, the high level of organization of investment activity, high level of investment adaptability of an enterprise. Scheme of the mechanism of formation of investment policy of the enterprise is represented in Fig. 5. 


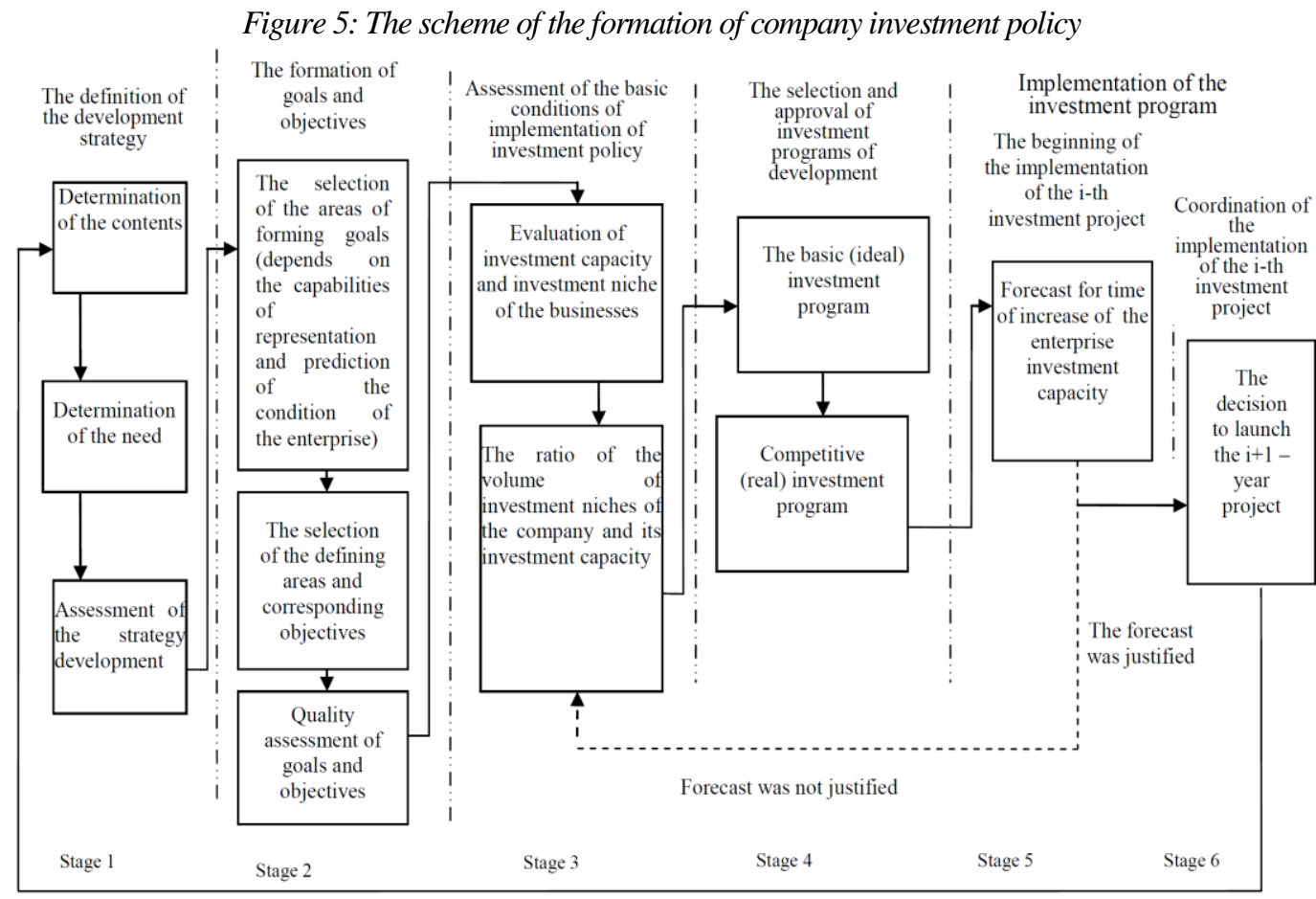

Source: The drawing is made by results of researches of authors

The set of all action management is broken down into six interrelated stages. In the first stage determines the enterprise development strategy, focused on the achievement of the investment stability. The second stage involves the formation of specific goals and objectives, it should be noted the necessary condition for the consideration of the enterprise as a complex, open and dynamic system. The third stage involves the estimation of the basic conditions of implementation of the investment policy. (Brickley \& James, 1987) Next, we define the ratio of the volume of businesses investment niche (VIN) and investment capacity (IC).

$$
\frac{V_{I N}}{I C} \geq 1
$$

If inequality (1) is true, then this suggests that all current needs of the enterprise investment resources can be satisfied. This is the ideal condition sought by each company. Deviation from it is due to the weakening financial, economic and organizational components of the enterprise stability. In the fourth stage based on the conditions of implementation or non-implementation of inequality (1) is developed by the investment program. At the fifth stage is the actual implementation of the $\mathrm{i}$-th investment project and forecasting of the beginning of the implementation of the $\mathrm{i}+1$-th investment project. The optimal moment to begin implementation of the $i+1$-th investment project, the time increment of investment capacity of the enterprise due to the implementation of the $\mathrm{i}$-th project.

In practice often present delay before the next project start, as a result, there is a lag of investments. The duration of investment lag consists of the time spent on the decision on the beginning of a new project $\left(\mathrm{T}_{\mathrm{D}}\right)$, time of search of the investors of investment project participants $\left(\mathrm{T}_{\mathrm{SI}}\right)$ and time of the coordination of interests $\left(\mathrm{T}_{\mathrm{CI}}\right)$, i.e.: $\mathrm{T}_{\mathrm{IP}}=\mathrm{T}_{\mathrm{D}}+\mathrm{T}_{\mathrm{SI}}+\mathrm{T}_{\mathrm{CI}}$.

The object of management by the enterprise objectively are two components of the lag of investment: decision-making time and the time of search of the investor. The time of decisionmaking develops from time spent on the evaluation of the filling of the investment capacity of the enterprise at the moment (in terms of investment project implementation), the time spent on 


\section{Methodical Bases of Formation of Investment Policy of Enterprises of \\ Construction Materials Industry \\ Authors: Oksana Aleksandrovna Baulina, Vladislav Vladimirovich Klyushin}

the analysis of the current needs of the enterprise investment resources, time, prediction of volume increment of investment capacity of the enterprise due to the implementation of the current project and the time of onset of the event. Future needs of the enterprise investment resources is determined by the formula:

$$
\frac{V_{A I}}{I C}=1
$$

where: $\quad \mathrm{V}_{\mathrm{AI}}$ - the amount actually attracted investment resources at the moment, IC investment capacity of the enterprise.

The value of this ratio may vary in the range from 0 to 1 . If this ratio equals 1 , then all the needs of the enterprise investment resources are currently satisfied, therefore, to start a new project impractical. The current need for investment resources is determined as the difference between the investment capacity of the enterprise and the amount actually borrowed resources.

The more accurate the predicted volume increments the investment capacity of the enterprise and the time of onset of the event, the less the duration of the lag of investment enterprises subject to the fulfillment of inequality (1). In fact, if the forecast is not justified, there is the reimplementation of the fourth and fifth stages, as long as the desired event does not occur. (Chaganti, 1985)

At the sixth stage starts directly the realization of the i+1-th investment project. The diagram at Fig. 5 represents a complete cycle of formation of the investment policy of the company. This enables a predictive assessment of the state enterprises, studies of dynamic processes with different source data and management strategies and the creation of many different potential scenarios of investment development. (Bell et al., 1991)

The proposed mechanism of formation of investment policy of the company allows to optimize the volume of investment niches and the duration of the lag of investment enterprises, and to solve a number of problems:

1. to determine the initial external conditions taking into account the uniqueness of the company, internal and external limitations on its business;

2. to determine the region of feasible solutions, select the best alternative options for implementation of strategic investment programmes;

3. the use of new forms, methods of planning, control, regulation factors of the investment component of the stability of the enterprises of building industry;

4. to evaluate intermediate and final results of implementation of strategic investment programmes;

5. to determine the dynamics of environmental factors, to take into account their interaction with the factors affecting investment certainty.

\section{Discussion}

Thus, in the present paper, the addition of investment theory in the framework of the following results pertaining to its scientific novelty:

- proved feasibility of the allocation of the investment component of the stability of the enterprises (along with financial, economic, organizational) in the formation of investment policy of enterprises of construction materials industry,

- given the author's definition of "investment component to the stability of the enterprise", "investment niche of the enterprise", "investment lag" and a proof of their consideration in the assessment of investment activity of enterprises with closed cycle of production 
of building materials industry, the development of the investment policy of the enterprises,

- proposed method of evaluation of "investment niche" and "duration of investment lag", which allows to determine the position of industrial enterprises of building materials in coordinate system "time - investment",

- articulated principles and developed structural and logical model of formation of investment policy of the enterprises of a closed cycle of production, taking into account the prognostic assessment of investment niches and the duration of investment lag.

\section{Conclusion}

So, in this paper theoretically proved the validity of the selection and evaluation of the investment component of the stability of the enterprises, given the definition of concepts it describes and proves the feasibility of recording such indicators of investment activity of enterprises, investment niche and lag of investments in the development of the investment policy of the enterprises of a closed cycle of production.

We analyzed the methodology used in the estimation of the factors and indicators of financial, economic, institutional and investment components stability of enterprises, including enterprises of material and technical base of construction. Comparative analysis of results to test these methods on the example of the enterprises of building materials industry, operating in the Volgograd region, revealed the advantages and disadvantages of their use in the development of the investment policy of the enterprises, functioning on the principle of the closed cycle of production. Also formulated the goal and objectives of the investment policy of the enterprise, the principles developed and presented to the structurally-logic scheme of formation of investment policy of enterprises of construction materials industry.

\section{References}

Baysinger, B.D. \& Butler, H.N. (1985). Corporate governance and the board of directors: Performance effects of changes in board composition. Journal of Law, Economics, and Organization, 1(1), 101-124.

Bell, T.B., Szykowny, S. \& Willingham, J.J. (1991). Assessing the likelihood of fraudulent financial reporting: A cascaded logit approach. Working paper, KPMG Peat Marwick, Montvale, NJ.

Brickley, J.A. \& James, C.M. (1987). The takeover market, corporate board composition, and ownership structure. The case of banking. The Journal of Law and Economics, 30, 161-180.

Chaganti, R.S., Mahajan, V. \& Sharma, S. (1985). Corporate board size, composition, and corporate failures in retailing industry. Journal of Management Studies, 22, 400-417.

DeAngelo, H. \& DeAngelo, L. (1990). Dividend policy and financial distress: An empirical investigation of troubled NYSE firms. The Journal of Finance, 45, 1415-1431.

DeAngelo, H., DeAngelo, L. \& Skinner, D.J. (1994). Accounting choice in troubled companies. Journal of Accounting and Economics, 17(1-2), 113-143.

Fama, E.F. (1980). Agency problem and the theory of the firm. Journal of Political Economy, 88, 288-308.

Feroz, E.H., Park, K. \& Pastena, V.S. (1991). The financial and market effects of the SEC's accounting and auditing enforcement releases. Journal of Accounting Research, 29, 107-142.

Gilson, S.C. (1990). Bankruptcy, boards, banks, and blockholders. Evidence on changes in corporate ownership and control when firms default. Journal of Financial Economics, 27(2), 355-387.

Grossman, S.J. \& Hart, O.D. (1980). Takeover bids, the free-rider problem, and the theory of the corporation. The Bell Journal of Economics, 2, 42-64.

Hermalin, B. \& Weisbach, M.S. (1988). The determinants of board composition. The Rand Journal of Economics, 19, 589-606.

Hermalin, E.B. \& Weisbach, S.M. (1991). The effects of board composition and direct incentives on firm performance. Financial Management, 20(4), 101-112.

Jensen, M.C. (1983). Separation of ownership and control. Journal of Law and Economics, 26, 301-325. 


\section{Methodical Bases of Formation of Investment Policy of Enterprises of \\ Construction Materials Industry \\ Authors: Oksana Aleksandrovna Baulina, Vladislav Vladimirovich Klyushin}

Jensen, M.C. (1993). The modern industrial revolution, exit, and the failure of internal control systems. The Journal of Finance, 48, 831-880.

Jensen, M.C. \& Meckling, W.H. (1976). Theory of the firm: Managerial behavior, agency costs and ownership structure. Journal of Financial Economics, 3(4), 305-360.

Kaplan, S.N. \& Reishus, D. (1990). Outside directorships and corporate performance. Journal of Financial Economics, 27(2), 389-410.

Kosnik, R.D. (1987). Greenmail: A study of board performance in corporate governance. Administrative Science Quarterly, 32, 163-185.

Maddala, G.S. (1991). A perspective on the use of limited-dependent and qualitative variables models in accounting research. The Accounting Review, 66, 788-807.

Morck, R., Shleifer, A. \& Vishny, R.W. (1988). Management ownership and market valuation. An empirical analysis. Journal of Financial Economics, 20, 293-315.

Novikova, G., Chub, A. \& Gushina, J. (2016). The effective management of the construction complex of the Region in the globalization conditions. Proceedings of the 16th International Scientific Conference Globalization and Its Socio-economic Consequences. Rajecke Teplice, Slovak Republic, 1547-1555.

Palepu, K.G. (1986). Predicting takeover targets. A methodological and empirical analysis. Journal of Accounting and Economics, 8(1), 3-35.

Palmrose, Z.V. (1987). Litigation and independent auditors: The role of business failures and management fraud. Auditing: A Journal of Practice \& Theory, 6, 90-103.

Patton, A. \& Baker, J. (1987). Why do not directors rock the boat? Harvard Business Review, 65, 10-12.

Pincus, K., Rusbarsky, M. \& Wong, J. (1989). Voluntary formation of corporate audit committees among NASDAQ firms. Journal of Accounting and Public Policy, 8(4), 239-265.

Rosenstein, S. \& Wyatt, J.G. (1990). Outside directors, board independence, and shareholder wealth. Journal of Financial Economics, 26(2), 175-191.

Shivdasani, A. (1993). Board composition, ownership structure, and hostile takeovers. Journal of Accounting and Economics, vol. 16, no. 1-3, pp. 167-198.

Shleifer, A. \& Vishny, R.W. (1986). Large shareholders and corporate control. Journal of Political Economy, 95 , 461-488.

Sommer A.A. (1991). Auditing audit committees: An educational opportunity for auditors. Accounting Horizons, 91-93.

Stone, M. \& Rasp, J. (1991). Tradeoffs in the choice between Logit and OLS for accounting choice studies. The Accounting Review, 66, 170-187.

Vancil, R. (1987). Passing the Baton: Managing the Process of CEO Succession. Boston, Massachusetts: Harvard Business School Press.

Vicknair, D., Hickman, K. \& Carnes, K.C. (1993). A note on audit committee independence: Evidence from the NYSE on "grey" area directors. Accounting Horizons, 7, 53-57.

Warner, J.B., Watts, R.L. \& Wruck, K.H. (1988). Stock prices and top management changes. Journal of Financial Economics, 20, 461-492.

Weisbach, M.S. (1988). Outside directors and CEO turnover. Journal of Financial Economics, 20, 431-460. 